\title{
PERLAWANAN AL-QURAN DAN HADIS TERHADAP KEMISKINAN
}

\author{
Muhammad Ali Musafak \\ Dosen STAI Grobogan \\ Email: malimusyafak13@gmail.com
}

\begin{abstract}
There is no doubt, that poverty is great danger of the religious beliefs, Especially extreme poverty severe, who were in front of the eyes of rich egoistic people. More worried, if poor people do not have jobs, and rich people do not want to give their hand. That is when the poverty will invite doubt against sunnatullah (provisions god) above this world. And cangive confidence in the injustice in a division of fortune. That is the dangerous of declining of aqeedah that is caused by poverty. As the word of Rasulullah, "almost poverty make people become atheist."Sayyidina Ali ra said that if the poverty like a men, I will kill them. Al Quran and Hadis give guidance to against poverty, the guidance has two aspects. The guidance from individual as hard work and simple living, and the guidance from social as management rakat productive, charity productive and infaq.
\end{abstract}

Keywords: Al-Quran, Hadis, and Poverty.

\begin{abstract}
Abstrak
Tidak diragukan lagi, bahwa kemiskinan merupakan bahaya besar terbadap kepercayaan agama. Khususnya kemiskinan yang sangat parah, yang berada di hadapan mata orang kaya yang egoistis. Lebih menghawatirkan lagi, jikea orang-orang miskin itu tidak menentu pencahariannya, sedangkan pihak orang-orang yang kaya sama sekali tidak mau mengulurkan bantuanya. Di saat itulah kemiskinanan akan mengundang keraguaan terbadap sunnatullah (ketentuan Allah) di atas dunia ini, serta dapat menimbulkan kepercayaan terbadap adanya ketidak adilan dalam pembagian rizki. Itulah bahaya kegoncangan aqidah yang ditimbulkan oleh kemiskinan dan kemlaratan: sebagaimna sabda Rasullah "bampir kemiskinan itu menjadikan seseorang kufur". Sayyidina Ali ra dalam pernyataan yang mashur mengatakan:" Seandainya kemiskinan itu berwujud seorang laki-laki maka aku akan membunubnya". al-Quran dan Hadis memberikan tuntunan dalam melawan kemiskinan, tuntunan ini terdapat dua aspek, Tuntunan yang berasal dari individu meliputi kerja keras, dan bidup sederhana sedangkan tuntunan yang berasal dari sosial kemasyarakatan yakni meliputi pengelolaan zakat produktif sedekah produktif dan infaq.
\end{abstract}

Kata Kunci: al-Quran dan Hadis, Kemiskinan. 


\section{A. Pendahuluan}

Kemiskinan merupakan satu problem pelik yang dihadapi umat manusia. Kompleksitas dari permasalahan ini juga berimplikasi terhadap rusaknya aspek kehidupan. Namun, masih banyak umat Islam yang memahami kemiskinan sebagai perangkat suci, terutama dalam hadis Rasululllah pada bab zuhud, kemiskinan diartikan sebagai karunia Ilahi, menuju sarana untuk mendekatkan diri kepada Tuhan. Kehadiranya di sambut sebagai kenyataan sekaligus lambang kesalehan dengan semboyan "miskin harta lebih baik daripada miskin hati dan budi".

Menurut Mustofa Abdul Wahid, bahwa memandang hina dunia bahkan mengharamkan dunia dengan segala isinya, merupakan ajaran yang banyak disebarkan kaum zahid pada masa awal kemunculanya bahkan menurut al-Ghazali ${ }^{2}$ banyak orang awam di kalangan umat Islam yang berpendapat bahwa kemiskinan di dunia adalah tanda kekayaan di akhirat. Pemahaman semacam ini sangat mungkin memunculkan bermacam hadis yang dipahami secara sempit seperti ini:

1. Hadis Rasul yang diriwayatkan Abu Said al-Khudriyyi " "Ya Allah bidupkan aku dalam kemiskinan, matikan aku dalam kemiskinan dan masukanlah aku pada golongan orang-orang miskin”.

2. Dari riwayat Ibn Hibban, Rasullah bersabda: "Diperlibatkan kepadaku surga, aku lihat didalamnya, sebagian besar penghuninya adalah kaum miskin".

3. Dari Abu Hurairah, rasullah saw bersabda: "Dunia itu penjaranya orang mukmin dan surganya orang kafir"”

Beberapa catatan di atas menunjukan adanya problem teologis yang menimpa sebagian besar umat Islam dalam memahami kemiskinan. Kesalahan interpretasi terhadap kemiskinan akan sangat menggangu usaha pengentasan kaum miskin di dunia Islam. Disamping problematika teologi di atas, ada kenyataan realistis kemiskinan yang menyatu dengan kehidupan sebagian besar umat Islam di dunia.

\footnotetext{
${ }^{1}$ M Nasihin Hasan, Kepedulian Sosial dalam Beragama, Majalah Pesantren (No.2/Vol.III/1986), hlm. 2.

2 Muhammad al-Ghazali , Al-Islam wa Auda' al-Iqtishadiyah,(Kairo:Dar al-Riyan.1987). hlm.137.

3 Yusuf Qardawy, Al-Muntaqa (al-Manshurah: Dar al-Wafa' 1993), hlm. 381.
} 
Hanya segelintir negara dengan mayoritas berpenduduk muslim, yang cukup makmur dan maju dalam perekonomian dan industrinya. Kebanyakan karena negara seperti Brunei Darussalam atau negara di kawasan Arab Teluk di dukung oleh faktor sumber daya alam yang melimpah dan bukan oleh sumber daya manusianya. Selebihnya, kebanyakan negara dengan warga mayoritas muslim rankingnya masih berada di bawah garis kemiskinan. Contoh nyata, lihat saja Pakistan, Sudan, Mesir, Bangladesh, Afganistan, Albania, Aljazair, Maroko, Mauritania, Chad, Azerbaijan, dan Sierra Leone.

Sebagaimana dengan pandangan al-Quran dan al-Hadis tentang kemiskinan secara implikasi penafsiran yang di ambil menjadi fokus tulisan ini dengan menitikberatkan pada cara ayat al-Quran dan hadis Rasulullah, teks keagamaan serta bermacam aspek terkait dengan kemiskinan menjadi perhatian utama. Juga cara Islam mendorong umatnya untuk bisa keluar dari jeratan kemiskinan.

\section{B. Gambaran Umum Kemiskinan}

Kemiskinan berasal dari akar kata miskin dengan awalan ke dan akhiran an yang menurut kamus Bahasa Indonesia mempunyai persamaan arti dengan kefakiran yang berasal dari akar kata fakir dengan awalan ke dan akhiran an. Kedua kata ini seringkali juga disebutkan secara bergandengan yakni fakir miskin dengan pengertian orang yang sangat kekurangan. Dalam Bahasa Arab kata miskin diambil dari kata sakana yang berarti diam atau tenang. Secara definitif diartikan sebagai keadaan tidak berharta benda atau serba kekurangan, (berpenghasilan rendah). ${ }^{4}$ Kemiskinan juga didefinisikan sebagai standar hidup yang rendah, yaitu adanya kekurangan materi pada sejumlah atau segolongan orang dibandingkan dengan standar kehidupan yang umum berlaku pada masyarakat. ${ }^{5}$ Standar kehidupan yang rendah ini secara langsung tampak pengaruhnya terhadap tingkat keadaan kesehatan, pemenuhan kebutuhan pokok dan sekunder.

\footnotetext{
4 Tim Penyusun, Kamus Besar Bahasa Indonesia (Jakarta: Balai Pustaka, 1990), hlm 587.

5 Parsudi Suparlan (ed), Kemiskinan di Perkotaan (Jakarta: Yayasan Obor Indonesia, 1995), hlm. XI.
} 
Pendapat yang lain menyebutkan bahwa kemiskinan merupakan ketidakmampuan individu dalam memenuhi kebutuhan dasar minimal untuk hidup layak, kondisi yang berada di bawah garis nilai standar kebutuhan minimum, baik untuk makanan dan non makanan, yang disebut garis kemiskinan (poverty line) atau batas kemiskinan (poverty threshold). Garis kemiskinan sendiri diartikan sebagai sejumlah rupiah yang diperlukan oleh setiap individu untuk dapat membayar kebutuhan makanan setara 2000-2500 Kg kalori per orang per hari dan kebutuhan non-makanan yang terdiri dari perumahan, pakaian, kesehatan, pendidikan, transportasi, serta aneka barang dan jasa lainnya. Kemiskinan pada umumnya didefinisikan dari segi pendapatan dalam bentuk uang ditambah dengan keuntungan non-material yang diterima oleh seseorang.

Kemiskinan bisa dikelompokkan dalam dua kategori, yaitu kemiskinan absolut dan kemiskinan relatif. Kemiskinan absolut mengacu pada satu set standar yang konsisten, tidak terpengaruh oleh waktu dan tempat (Negara). Contohnya, persentase dari populasi yang makan di bawah jumlah yang cukup menopang kebutuhan tubuh manusia (kira- kira 2000-2500 kalori per hari untuk laki laki dewasa).

Bank Dunia mendefinisikan kemiskinan absolut sebagai hidup dengan pendapatan di bawah USD $\$ 1 /$ hari dan kemiskinan relatif untuk pendapatan dibawah $\$ 2$ per hari, dengan batasan ini maka diperkiraan pada 2011, sekitar 1,7 miliar orang di dunia mengkonsumsi kurang dari $\$ 1 /$ hari dan 2,7 miliar orang di dunia mengkonsumsi kurang dari \$2/hari." Proporsi penduduk negara berkembang yang hidup dalam kemiskinan ekstrem telah turun dari 28\% pada 1990 menjadi 21\% pada 2001. Melihat pada periode 1981-2011, persentase dari penduduk dunia yang hidup dibawah garis kemiskinan \$1 dolar/hari telah berkurang separuh. Tetapi, nilai dari $\$ 1$ juga mengalami penurunan dalam kurun waktu diatas.

Meskipun kemiskinan yang paling parah terdapat di dunia bekembang, ada bukti tentang kehadiran kemiskinan di setiap region. Di negara maju, kondisi ini menghadirkan kaum tuna wisma yang berkelana ke sana kemari dan daerah pinggiran kota dan ghetto yang miskin. Kemiskinan dapat di lihat sebagai kondisi kolektif masyarakat miskin, atau kelompok miskin, dan keseluruhan negara yang terkadang dianggap miskin. 
Untuk menghindari stigma ini, bermacam negara ini biasanya disebut sebagai negara berkembang.

\section{Faktor-faktor Kemiskinan}

Menurut Ali Yafie, terdapat petunjuk dari satu hadis yang mengungkapkan penyebab kemiskinan dengan bunyi:

"...............aku mohon supaya Engakau (Tuhan) melindungi aku dari kelemaban (al-aj₹), kemalasan, ketakutan, kepelitan, terlilit butang dan diperas atau dikuasai sesama manusia."

Didalamnya tercantum perkara pokok yang menimbulkan kemiskinan yang memelaratkan, seperti:

1) Kelemahan, baik kelemahan hati dan semangat atau kelemahan akal dan ilmu, atau kelemahan fisik. Semua itu mengurangi daya pilih dan daya upaya manusia sehingga tidak mampu menjalankan fungsinya sebagai pencipta dan pembangun untuk memenuhi kebutuhan hidupnya.

2) Kemalasan, tidak diragukan lagi bahwa sifat ini merupakan pangkal utama dari kemiskinan. Penataan hidup sehari-hari yang diajarkan oleh Islam sangat bertolak belakang dengan sifat ini.

3) Ketakutan, jelas merupakan penghambat utama untuk mencapai kesuksesan dalam pekerjaan dan usaha. Keberhasilan seseorang dalam merintis atau melanjutkan sesuatu atau tugas banyak tergantung dari keberaniann yang ada pada dirinya.

4) Kepelitan, banyak bersangkutan dengan pihak si kaya, karena dengan sifat ini tanpa disadari kepelitannya itu membantu untuk tidak mengurangi kemiskinan dan menempatkan dirinya menjadi sasaran untuk dihindari oleh si miskin.

5) Terlilit hutang, terdapat banyak peringatan dari ajaran Islam untuk berhati-hati untuk tidak sampai terjerat hutang karena sangat membelenggu kebebasan di dunia maupun di akhirat. Apalagi yang sudah terbiasa dengan membiayai 
hidupnya dari hutang, maka sulit sekali mengangkat dirinya dari lumpur kemiskinan.

6) Di peras atau dikuasai sesama manusia, merupakan penyebab bagi timbulnya banyak penderitaan dan kemlaratan, baik pada tingkat perorangan, masyarakat bangsa dan Negara. Pemerasan manusia kuat hubunganya dengan sistem perbudakan dan pemerasan manusia kaya menimbulkan riba sedangkan pemerasan pada tingkat masyarakat, bangsa dan Negara menimbulkan sistem kapitalisme yang berkembang menjadi imprealisme. ${ }^{6}$

Menurut Saad, berbagai sebab terjadinya kemiskinan terkait dengan model interaksi antara manusia dengan dirinya sendiri, dengan sesamanya, dengan alam, dan dengan masyarakatnya. Penyebab kemiskinan yang terkait dengan kondisi alam terjadi bila dilakukan pola destruktif antara manusia dan alam, seperti eksploitasi besar-besaran terhadap alam tanpa melakukan analisis dampak lingkungan. Akibat lebih lanjut dari kejadian ini adalah kemiskinan baik secara langsung maupun tidak langsung, baik generasi yang sedang eksis maupun generasi selanjutnya. Sedangkan berbagai penyebab kemiskinan yang berkaitan dengan kondisi manusia sendiri adalah kurangnya percaya diri terhadap kemampuannya, keengganan mengaktualisasi potensi yang ada dalam bentuk kerja nyata yang serius serta keengganan memberikan respek optimal terhadap perputaran waktu. Penyebab kemiskinan yang berkaitan dengan kondisi sosial, adalah terkonsentrasinya modal di tangan orang-orang kaya, sehingga menyebabkan orang fakir maupun miskin tidak banyak memiliki kesempatan untuk mengaktualisasi potensipotensi dirinya demi meraih prestasi di bidang ekonomi.

Menurut teori development of under development atau teori ketergatungan-dominasi (dominance-depedency) bahwa berbagai penyebab kemiskinan dan keterbelakangan bukanlah sekedar faktor yang terdapat pada masyarakat yang bersangkutan seperti kurangnya modal, pendidikan yang rendah, kepadatan penduduk, maupun kurangnya gizi. Lebih dari itu, faktor diatas hanya dianggap atribut kemiskinan saja, tetapi yang lebih riil berakar

6 Wildana Wargadinata, Islam dan Pengentasan Kemiskinan, (Malang: UIN Maliki Press, 2001), hlm.19. 
dari sejarah eksploitasi, terutama yang yang dilakukan kekuatan kapitalis asing atau internasional yang melakukan penetrasi, dominasi dan pengerukan keuntungan dari daerah pinggiran ke pusat-pusat kota.

\section{Kemiskinan dalam pandangan al-Quran}

Para pakar agama Islam berbeda pendapat dalam menetapkan tolak ukur kemiskinan dan kefakiran. Sebagian mereka berpendapat bahwa fakir adalah orang yang berpenghasilan kurang dari setengah kebutuhan pokoknya, sedangkan miskin adalah orang yang berpenghasilan di atas itu, namun tidak cukup untuk memenuhi kebutuhan pokoknya. ${ }^{7}$ Ada juga yang mendefinisikan sebaliknya, sehingga menurut mereka keadaan si fakir relatif lebih baik dari si miskin. Secara langsung, tidak ada informasi al-Quran dan hadis dalam menetapkan angka tertentu lagi pasti sebagai ukuran kemiskinan karena yang ada adalah perintah untuk menyantuni orang miskin, larangan menzalimi mereka, serta larangan menumpuk harta. Ini menunjukan bahwa al-Quran memandang, kemiskinan sebagai problem yang serius dan harus dicarikan solusinya. ${ }^{8}$

Al-Quran menggambarkan kemiskinan dengan 10 kosakata yang berbeda, yaitu alMaskanat (kemiskinan), al-Faqr (kefakiran), al-'Ailat (mengalami kekurangan), al-Ba'sa (kesulitan hidup), al-Imlaq (kekurangan harta), al-Sail (peminta), al-Mahrum (tidak berdaya), al-Qani (kekurangan dan diam), al-Mu'tarr (yang perlu di bantu) dan al-Dha'if (lemah) dengan penjelasan berikut: Pertama: Miskin, diantara sejumlah term menyangkut kemiskinan yang digunakan al-Quran, maka pertama kali yang disebut adalah kata miskin. Kata ini dari segi bentuknya, termasuk al-Shifat al-Musabbahat (kata yang menunjukan keadaan dan tidak terkait dengan waktu) dan menunjuk pada orang yang tidak mempunyai harta benda. Kata ini dibentuk dari fïil madhi (kata kerja bentuk lampau)

\footnotetext{
7 M Quraish Shihab, Wawasan al-Qur'an; Tafsir Maudu'I atas Berbagai Persoalan Ummat (Bandung:Mizan, 1997), hlm. 449.

${ }^{8}$ Yusuf al Qardawy, Sistem Masyarakat Islam dalam al-Qura'an dan Sunah, (Solo: Citra Islam Press, 1997), hlm 340.
} 
sakana diamnya sesuatu yang sudah bergerak, dan bertempat tinggal sedangkan bentuk masdarnya adalah maskanat (kemiskinan). ${ }^{9}$

Kata miskin dalam bentuk mufrad digunakan sebanyak 11 kali. Bentuk jamaknya masakin digunakan 12 kali, sedangkan bentuk masdarnya maskanat digunakan sebanyak 2 kali. ${ }^{10}$ Keterangan ini menunjukan bahwa menyangkut pemakaian kosa kata miskin, alQuran lebih banyak menggunakan kata sifat atau orang yang menyandang sifat miskin di banding menggunakan masdar atau kata benda yang menunjukan perihal miskin. Ini berarti al-Quran lebih banyak menyoroti kemiskinan sebagai persoalan manusia atau sifat yang berhubungan dengan diri manusia terlihat dari penggalan ayat ini:

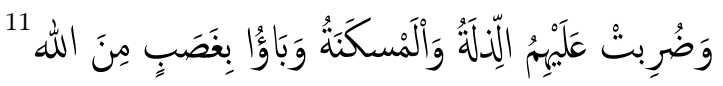

Kedua: al-Faqr, termasuk jenis ism (kata benda) bentuk masdar. Kata kerja bentuk lampaunya adalah fuqara' dan al-Faqir (jamaknya fuqara'). Dari segi etimologi, al-Faqir berarti orang yang patah tulang belakangnya. Kata ini kemudian dipergunakan untuk arti kata "orang miskin". Ia seolah-olah patah tulang belakangnya karena kemiskinan dan kesengsaraan. Kata al-Faqr digunakan sekali saja di dalam al-Quran. Adapun al-Faqir digunakan sebanyak lima kali, dan jamaknya al-fuqara' digunakan sebanyak tujuh kali. Ini menunjukan bahwa frekuensi pemakaian kosakata dalam bentuk kata sifat lebih banyak dibanding kata benda bentuk masdar. Kata al-faqr mengarah pada materi yang terdapat pada (Q.S al-Baqarah [2]:268) berikut:

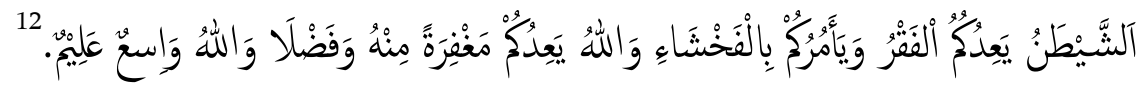

Imam Thabari dalam tafsirnya menerangkan bahwa maksud dari kata fuqarā'adalah orang yang sangat membutuhkan bantuan untuk meringankan

${ }^{9}$ Lihat al-Raghib al-Ashfahany, Mufradz al-Fazh al-Qur'an, (Bairut: al- Dar al-Saamiyyah, 1992) hlm.417-418.

${ }^{10}$ M Fuad 'Abd al-Baqiy, al-Mu'jam al-mufahras li al-Fadz al-Qur'an al-Karim (Bairut: Dar al-Fikr, 1986) hlm.352.

11 Artinya: Dan mereka ditimpa nasib yang bina dan kemiskinan dan mereka mendapat murka dari Tuban......(Q.S al-Baqarah [2]:61)

12 Artinya: setan itu menjanjikan kepadamu kemiskinan (jika kamu mau bersedekah) dan menyuruh kamu berbuat keji, dan Allah menjanjikan kepadamu suatu ampunan daripada-Nya dan karunia (jika bersedekab) dan Allah maha luas karunia-Nya dan Maha Mengetabui (Q.S. al-Baqarah [2]:268). 
bebannya, (الحتاجون المتعفقون عن المسألة), sedangkan masaakin ialah orang yang keliling untuk meminta-minta (الطوافين السائين (13)

Menurut M. Rasyid Ridha, jumhur ulama berpendapat bahwa al-fuqara' dan almasakin $^{14}$ adalah dua golongan manusia yang berdiri sendiri, namun mereka berbeda pendapat dalam memberikan pengertian terhadap kata itu. Sebagian ulama berpendapat bahwa al-fuqara' mempunyai keadaan yang lebih buruk secara ekonomi dari pada almiskin, namun sebagian lainnya berpendapat sebaliknya. Ada juga sebagian ulama termasuk juga ia sendiri, berpendapat bahwa kedua nama itu dua pembagian dari satu golongan. Keduanya berbeda dari segi karakteristik, dan bukan dari segi jenisnya. Alasanya, kedua kata di atas tidak digunakan secara bersamaan dalam al-Quran kecuali pada surat at-Taubah.

Menurut M. Mahmud al-Hijazy, Miskin tergolong manusia faqir yang masih membutuhkan materi. Orang miskin mempunyai harta yang tidak mencukupi kebutuhanya. Adapun faqir itu, tidak mempunyai harta sehingga mereka lebih utama untuk diberi bantuan secara materi. ${ }^{15}$ Sedangkan menurut Yusuf al-Qaradhawi, al-fakir tidak mempunyai apapun atau hanya mampu menutupi setengah dari kebutuhan dirinya dan orang yang menjadi tanggunganya, sedangkan al-Miskin dapat memenuhi setengah atau lebih dari setengah kebutuhanya, namun belum sampai seluruhnya. ${ }^{16}$ Adapun menurut hemat penulis, mengikuti pendapat yang dianut sebagian besar ulama fikih (fuqaha) bahwa, fakir dan miskin secara bersama menyandang kemiskinan, hanya saja kadar kemiskinannya yang berbeda. Miskin adalah orang yang berada pada taraf tertentu

13 Abu Yahya Muhammad Ibn Shumadih at-Tujibiy, Mukhtashar min Tafsir al-Imam atThabariy, (Kairo: tt: Dar al-Manar lin-Nasyr wa at-Tauzi'), hlm. 196.

${ }^{14}$ Lihat (Q.S at-Taubah [9]:60) .18.

15 M Mahmud Hijazy, al-Tafsir al-wadhi, juz III, (Kairo: Mathaba' at-Istiqlal al-Qubra, 1968), hlm hlm.81.

${ }^{16}$ Yusuf al-Qardawy, Musykilat al-Faqr wa Kaifa 'Alajaha' al-Islam (Kairo: Maktabah Wahbat, 1986),

177 @2017 Islamic Review: Jurnal Riset dan Kajian Keislaman 
dalam arti dapat memenuhi setengah atau lebih dari setengah kebutuhanya sedangkan Faqir berada dibawahnya. Kedudukan fuqara' lebih berhak mendapat bantuan materiil, baik itu berupa zakat maupun shadaqah.

Ketiga: al-Ailat, adalah kata benda bentuk masdar yang berarti kemiskinan. Kata kerja bentuk lampaunya adalah 'ala (mengalami kemiskinan) seperti kalam kalimat عَالَ الَرجُلْ orang itu mengalami kemiskinan). Kata benda yang menunjukan kepada penyandang kemiskinan (ism fail) disebut 'ail. Kata 'ail sendiri digunakan untuk sebutan orang yang mempunyai banyak tanggungan keluarga. Kata 'ailat sebagai bentuk masdar digunakan sekali saja didalam al-Quran yakni pada surat (at-Taubah [9]: 28), sedangkan kata 'ail sekali saja dalam al-Quran yakni terdapat pada surat (al-Dhuha [93]: 8). Kedua ayat tersebut menunjukan arti bahwa sesungguhnya manusia dalam keadaan miskin, dan Allah lah yang membuat ia menjadi kecukupan secara materi. Khusus pada surat (at-Taubah [9]: 28) yang menjelaskan bahwa Rasulullah dilahirkan dalam keadaan yatim dan tergolong miskin. Ia tidak mewarisi harta benda dari ayahnya yang meninggal selagi ia masih dalam kandungan ibunya, melainkan seekor unta dan seorang budak wanita. Kecukupan (ghina) yang diberikan Allah kepada Rasulullah menurut Muhammad Abduh diberikan Tuhan melalui keuntungan perdagangan dan harta pemberian Khadijah.

Keempat: al-Ba'sa, kata al-Ba'sa terambil dari kata al-Bu's. (bentuk masdar) dan berarti kesulitan karena kemiskinan. al-Bu's menurut Ibn Zakariya, berarti kesulitan dalam penghidupan. Kata kerja bentuk lampaunya adalah bausa. Al-Ba'sa digunakan sebanyak empat kali di dalam al-Quran, sedangkan al-bais, yang berarti orang melarat digunakan sekali saja. ${ }^{17}$ Al Ba'sa dikemukakan dalam empat gagasan pokok yaitu bersabar dalam kesempitan dan penderitaan merupakan satu unsur dari al-Birr (kebijakan), (Q.S alBaqarat [2]:177). Malapetaka dan kesengsaraan merupakan cobaan bagi calon penghuni surga sebagaimana hal itu ditimpakan kepada umat terdahulu (Q.S al Baqarat [2]: 214).

Kata al-Ba'is, yang berarti orang miskin dugunakan sekali saja di dalam al-Quran yakni pada surat( al-Hajj [22]: 28) dengan maksud:

\footnotetext{
${ }^{17}$ M Fuad Abdul Baqiy, al-Mu'jam al Fahrs .........hlm.113.
} 
Kata al-Ba'is pada ayat di atas dirangkaikan dengan kata al-Fagir dalam hubungan al-Shiffah dan al-Mausuf (diterangkan dan menerangkan). Artinya bahwa, orang sengsara yang dimaksud dalam ayat itu terutama disebabkan oleh faktor ekonomi.

Kelima: al-Imlaq, merupakan kata benda berbentuk masdar. Kata kerja bentuk lampaunya amlaqa artinya, menghabiskan harta benda sehingga menjadi orang yang kekurangan. ${ }^{19}$ Dengan demikian, dari segi leksikal, kemiskinan yang di tunjuk oleh kata itu terkait dengan tindakan manusia berkenaan dengan harta benda. Kata ini hanya digunakan sebanyak dua kali dalam al-Quran, dan keduanya dalam bentuk masdar. Selain itu keduanya digunakan dalam konteks masalah yang sama, yaitu larangan membunuh anak-anak karena faktor kemiskinan sebagaimana terdapat pada surat al-Isra'[17]:31.

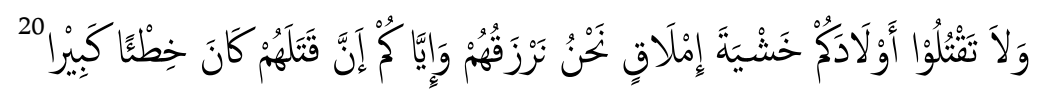

Imlaq yang di maksud pada ayat di atas berarti kemiskinan. Partikel min (dari) yang mendahului kata itu mengandung arti sebab. Min Imlaq berarti karena kemiskinan. Jadi, ayat itu berisi larangan terhadap orang tua untuk membunuh anak-anak mereka karena kemiskinan yang menimpa mereka. Dalam ungkapan Muhammad Rasyid Ridha, janganlah kamu membunuh anak-anakmu yang masih kecil karena kemiskinan yang menimpa kamu, yakni dengan membiarkan mereka kelaparan di rumahmu.

Keenam: al-Sail merupakan isim fail (kata benda yang menunjukan pelaku perbuatan) berbentuk dari kata kerja sa'ala yang artinya meminta kebaikan, atau perkara

${ }^{18}$ Artinya: "Maka makanlah sebagian daripadanya dan (sebagian lagi) berikalah untuk dimakan orang-orang yang sengsara lagi fakir "(Q.S al-Hajj [22]:28).

351.

${ }^{19}$ Ibn Zakariya, Mu'jam Mawayis al-Lughat, jilid V (Mesir: Musthasfa al Baby al-Halaby, 1997), hlm.

20 Artinya: Dan janganlab kamu membunub anak-anak kamu karena takut kemiskinan. Kamilah yang akan member rizki kepada mereka dan juga kepadamu. Sesunggubnya membunub mereka adalab dosa yang besar. 
yang dapat membawa kepada kebaikan, meminta harta atau perkara yang dapat menghasilkan harta. Jadi, al-Sa'il adalah orang yang meminta sesuatu, baik itu immaterial seperti informasi atau berupa materi seperti upah atau uang. Berdasarkan keterangan di atas, maka arti miskin yang terdapat pada kata sa'ala hanya dapat ditelusuri pada pemakaian bentuk isim al-Fa'il baik bentuk tunggal (al-Sa'il) maupun bentuk jamak (alSailin). Semuanya merujuk pada arti dasar yakni bertanya atau meminta sesuatu.

Kata al-Sail (bentuk tunggal) digunakan sebanyak empat kali di dalam al-Quran. Tiga diantaranya mengandung arti orang miskin, sedangkan satu lainnya mengandung arti orang yang bertanya. Para orang miskin pada ayat itu dinyatakan mempunyai hak pada harta yang dipunyai oleh orang kaya (Q.S al-Zariyat [5] 19 dan Q.S al-Ma'arijj [70]: 25), orang-orang yang meminta-minta itu tidaklah dihardik (Q.S al-Dhuha[93]:10) berikut bunyi ayatnya:

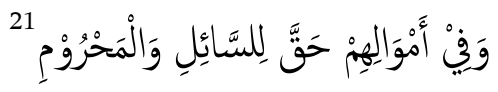

Kata, al-Sailin (bentuk jamak) digunakan sebanyak tiga kali di dalam al-Quran. Satu kali kata itu dipakai dalam arti orang yang meminta-minta (Q.S al-Baqarat [2]: 177) dan dua kali dipakai dalam arti orang yang bertanya (Q.S Yusuf [12]:7) dan (Q.S Fushilat [41]: 10).

Ketujuh: al-Mahrum, kata ini merupakan isim maf'ul (kata benda yang menunjukan obyek ) yang berarti orang yang terlarang untuk memperoleh kebaikan atau harta. Terbentuk dari kata kerja bentuk lampau haruma yang artinya terlarang, sedangkan bentuk masdarnya haram. Menurut al-Raghib al-Asfahany, adalah perkara yang di larang baik karena penggarisan Tuhan maupun oleh manusia, baik di larang dengan kekerasan maupun dari segi akal atau syariat, atau karena keadaannya.

Kata al-Mahrum digunakan sebanyak dua kali di dalam al-Quran. Penggunaan kata ini dalam bentuk tunggal selalu disebutkan sesudah kata al-Sail. Ini menunjukan bahwa antara kedua kata diatas terdapat kaitan makna, yakni secara bersama menunjuk kepada orang miskin, namun karakteristik yang di tunjuk tidak sama. Al-Sail diidentifikasikan

21 Artinya: Dan pada harta-barta mereka ada hak untuk orang miskin yang meminta dan orang miskin yang tidak mendapat bagian (tidak meminta). (Q.S al-Zariyat[51]: 19). 
dengan perbuatan mengemis, sedang al-Mahrum tidak menunjuk kata diatas tepatnya pada (Q.S al-Ma'arij[70]:24-25) sedangkan bentuk jamak dari al-Mabrum, yakni mahrumun disebutkan sebanyak dua kali. Pada surat al-Qalam [68]: 27, kata ini dipergunakan dalam arti orang yang dihalangi untuk memperoleh hasil kebunnya, atau tidak mendapatkan hasil sama sekali.

Kedelapan: al-Qani' adalah kata benda yang menunjuk kepada pelaku. Bisa di bentuk dari kata kerja lampau qani'a yang berarti merasa senang dan bisa dari qana'a yang berarti meminta. Menurut sebagian ahli bahasa, al-Qani' adalah permintaan yang tidak nyinyir dan merasa senang dengan perkara yang diperoleh. Kata al-Qani disebut sekali saja di dalam al-Quran yakni:

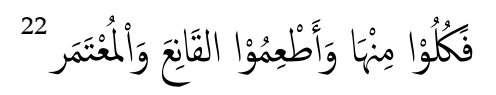

Pada ayat di atas, kata al-Qani' disebutkan dalam arti orang miskin yang rela dan tidak meminta-minta. Ia disebut sebagai satu golongan manusia yang kepadanya daging kurban itu diperuntukan. Dalam susunan redaksi itu, al-Qani' di sebut lebih dahulu dari al-Mu'tarr yang berarti orang yang meminta.

Kesembilan: al-Mu'tarr, disebutkan sekali dalam al-Quran, seperti yang terdapat pada ayat di atas yang berarti orang miskin yang meminta. Artinya sama dengan al-Qani' selaku penyandang kemiskinan, namun berbeda dari segi penampilan lahiriahnya. Untuk mendapat perkara yang dicarinya, ia mendatangi seseorang dengan meminta atau diam. Dalam hubungan ini Ibn Zakariya menambahkan bahwa ia seolah-olah sebagai orang yang dilindungi dan sudah terbiasa.

Kesepulub: al-Dhaif dan al-Mustadh'af, yang berarti lemah atau orang lemah. Dibentuk dari kata kerja lampau dha'ufa yang artinya menjadi lemah. Bentuk masdarnya

22 Artinya: maka makanlah sebagiannya dan beri makanlah orang rela dengan apa padanya (yang tidak meminta-minta) dan orang yang meminta (Q.S al-Haji [22]36). 
al-Dha'af berarti kelemahan atau antonim dari kekuatan. Kelemahan bisa terjadi pada jiwa, fisik, dan keadaan. Dengan demikian al-Dha'if dalam kaitannya dengan manusia bisa timbul karena dirinya atau keadaan yang berhubungan dengan dirinya. Kata al-Dha'if disebutkan empat kali di dalam al-Quran yaitu; 1) Nabi Syu'aib di anggap orang yang lemah kaumnya, tidak berwibawa (Q.S Hud [11]: 91, 2) orang yang lemah akal atau lemah keadaanya hendaknya dibantu oleh walinya dalam menuliskan hutangnya (Q.S al-Baqarah [2]: 282), 3) Sifat lemah itu kodrat manusia (Q.S al-Nisa' [4]: 28) 4) tipu daya setan itu lemah (Q.S al-Nisa' [4]: 76). Dari ayat di atas bisa di lihat bahwa al-Dha'if mempunyai berbagai konotasi, seperti tiada kekuasaan dan keadaan lemah. Segi ekonomi sebagai satu faktor dari kelemahan itu tercakup secara implisit seperti pada (Q.S Hud [11]: 91, 2) dan (Q.S al-Baqarah [2]: 282), 3).

Kesepuluh kosakata di atas menyandarkan pada satu arti atau makna yaitu kemiskinan dan penanggulangannya. Islam menyadari bahwa dalam kehidupan masyarakat akan selalu ada orang kaya dan orang miskin (QS An-Nisa [4]: 135). Sungguh, ini memang sejalan dengan sunatullah sendiri. Hukum kaya dan miskin sesungguhnya adalah hukum universal yang berlaku bagi semua manusia, apa pun keyakinannya. Karena itu tak ubahnya seperti kondisi sakit, sehat, marah, sabar, pun sama dengan masalah spirit, semangat hidup, disiplin, etos kerja, rendah hati dan mentalitas.

\section{E. Kemiskinan dalam pandangan Hadis Rasulullah S.A.W}

Ada banyak hadis Rasul menilai bahwa "kemiskinan" merupakan perkara yang sangat berbahaya terhadap kehidupan individu dan masyarakat, aqidah dan kepercayaan, pikiran dan kebudayaan, demikian pula terhadap keluarga dan bangsa seluruhnya. Dalam satu hadis dijelaskan:

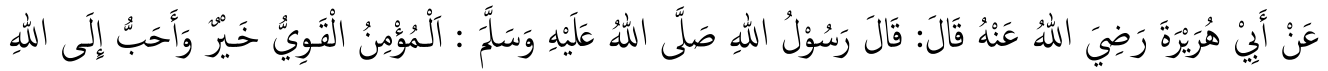

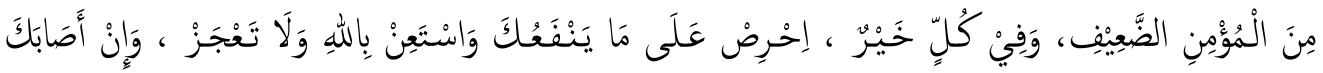




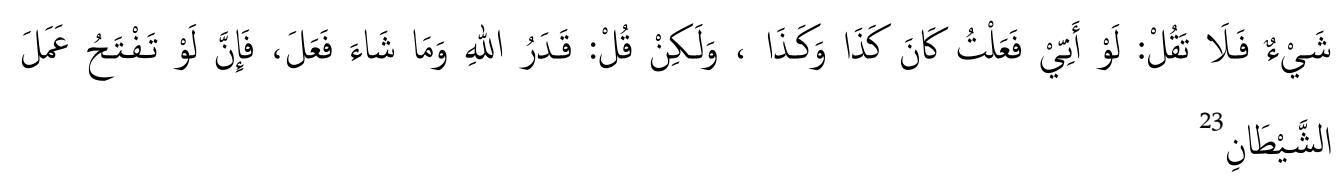

Sabda Rasulullah S.A.W :

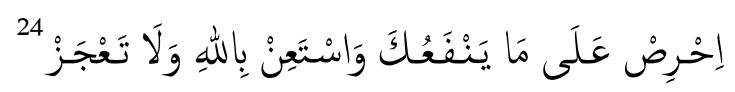

Sabda Rasulullah S.A.W ini mengandung arti luas dan penuh manfaat, mencakup kebahagiaan dunia dan akhirat. Perkara yang bermanfaat itu ada dua macam berupa perkara yang bermanfaat dalam agama dan perkara bermanfaat dalam keduniaan. Seorang hamba membutuhkan kebutuhan dunyawiyyah (keduniaan) sebagaimana ia membutuhkan kebutuhan diniyyah (keagamaan). Kebahagiaan seorang hamba dan kesuksesannya sangat ditentukan oleh semangat dan kesungguhannya dalam melakukan segala yang bermanfaat dalam urusan agama dan dunianya, serta keriusannya dalam memohon pertolongan kepada Allâh Azza wa Jalla. Ketika semua unsur ini sudah terpenuhi, maka ini merupakan kesempurnaan baginya dan sebagai tanda kesuksesannya. Namun, ketika dia meninggalkan salah satu dari tiga perkara ini (bersemangat, bersungguh-sungguh, dan meminta pertolongan Tuhan), maka dia akan kehilangan kebaikan seukuran dengan perkara yang ditinggalkannya.

Orang yang tidak bersemangat dalam meraih dan melakukan perkara yang bermanfaat bahkan bermalas-malasan, maka dia tidak akan mendapatkan apapun karena malas itu sumber kegagalan. Orang yang malas tidak akan mendapatkan kebaikan dan

\footnotetext{
23 Artinya: Dari Abu Hurairah Radbiyallahu 'anhu, beliau berkata, Rasûlullâh Shallallabu 'alaibi wa sallam bersabda, Mukmin yang kuat lebih baik dan lebih dicintai Allâh Azza wa Jalla daripada Mukmin yang lemab; dan pada keduanya ada kebaikan. Bersunggub-sunggublab untuk mendapatkan apa yang bermanfaat bagimu dan mintalah pertolongan kepada Allâh (dalam segala urusanmu) serta janganlah sekalikali engkau merasa lemah. Apabila engkau tertimpa musibah, janganlab engkau berkata, Seandainya aku berbuat demikian, tentu tidak akan begini dan begitu, tetapi katakanlah, Ini telah ditakdirkan Allahb, dan Allahb berbuat apa saja yang Dia kehendaki, karena ucapan seandainya akan membuka (pintu) perbuatan setan.

24 Artinya: Bersungguh-sunggublah untuk meraih apa yang bermanfaat bagimu dan mintalah pertolongan kepada Allâh (dalam segala urusanmu).
} 
kemuliaan. Orang yang malas tidak akan bernasib baik dalam agama dan dunianya dan ketika dia semangat tetapi bukan pada perkara yang bermanfaat, seperti bersemangat pada perkara yang membahayakan dan menghilangkan kebaikan, maka ujung dari kesemangatannya adalah kegagalan, kehilangan kebaikan, mendapatkan keburukan dan kerugian. Berapa banyak orang yang bersemangat untuk meraih dan menempuh cara dan perkara yang tidak bermanfaat, akhirnya ia tidak mendapat faedah apapun dari kesemangatannya melainkan rasa lelah, payah dan susah.

Jika ada orang menempuh jalan yang bermanfaat, bersemangat dan bersungguhsungguh padanya, namun tidak disertai dengan keseriusannya dalam memohon pertolongan kepada Allâh Azza wa Jalla, maka hasil yang akan dipetiknya tidak maksimal. Jadi benar-benar bersandar kepada Allâh Azza wa Jalla dan memohon pertolongan kepada-Nya bertujuan agar bisa mendapatkan perkara yang bermanfaat secara maksimal. Orang seperti ini tidak hanya bertumpu pada dirinya, kedudukannya dan kekuatannya, tetapi ia bertumpu sepenuhnya kepada Allâh Azza wa Jalla .

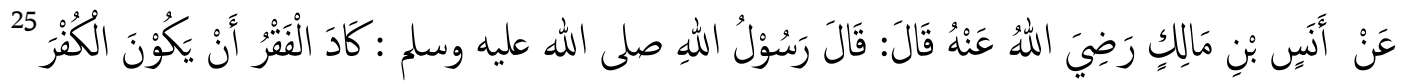

Hadis ini dikeluarkan oleh Imam al-Baihaqi dalam kitab Syu'abul Iman (No 6612), Abu Nu'aim al-Ashbani dalam Hilyatuol Auliya' (3/53 dan 109), al-Qudha-I dalam Musnadusy Syihab (No.586), al-'Uqaili dalam adh-Dhuafa'(No.1979) dan Ibn 'Adi' dalam al-Kamil(7/236), semuanya dari berbagai jalur, dari Yazid bin Aban ar-Raqasyi dari Anas Ibn Malik ra. dari Rasullah S.A.W.

Rasulullah S.A.W juga pernah memohon perlindungan kepada Tuhan dari ancaman kemelaratan yang disejajarkan dengan permohonan perlindungan terhadap kekufuran, seperti yang dijelaskan oleh hadis riwayat Abu Daud, bahwa Rasullah pernah berdoa: "Ya Tubanku, aku berlindung kepada-Mu, dari babaya kekufuran dan kemelaratan. Dalam doa yang lain, seperti yang dijelaskan dalam Hadist riwayat Abu Daud, an-Nasai, Ibn Majah, Hakim dari Abu Hurairoh, bahwa Rasullah berdo'a: Ya Tuhanku, aku

25 Artinya: Dari Anas Ibn Malik r.a bahwa Rasullab saw. haampir saja kefakiran (kemiskinan) menjadikan kekafiran. (H.R At-Thabrani) 
berlindung kepada-Mu, dari Kemiskinan, kekurangan dan kebinaan, dan aku berlindung dari menganiaya dan dianiaya.

\section{F. Konsep Pengentasan Kemiskinan al-Quran dan Hadis}

Islam hadir dengan spirit menyelamatkan, membela, dan membebaskan manusia dari kondisi ketidakadilan dalam ranah sosial-ekonomi. Islam mempunyai pandangan yang positif terhadap harta dan etos kerja untuk mengatasi kemiskinan, karena Islam tidak setuju dengan pandangan yang menyatakan bahwa kemiskinan adalah sarana penyucian diri. Dalam konteks ini, ada banyak ayat al-Quran maupun hadis Rasulullah yang dapat digunakan sebagai rujukan diantarannya:

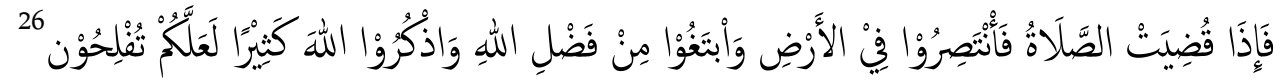

Sejak dini pula al-Quran mengingatkan Rasulullah tentang betapa besar anugerah Tuhan kepadanya, antara lain menjadikanya kecukupan setelah sebelumnya kekurangan. Seandainya, kecukupan atau kekayaan tidak terpuji, niscaya ia tidak dikemukakan oleh bunyi ayat ke-8 al-Dhuha:

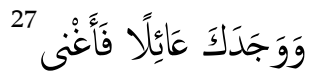

Upaya pemenuhan hajat hidup agar mendapat kesejahteraan merupakan anjuran, bahkan ada ayat yang memperbolehkan seseorang untuk mencari karunia dan kelebihan materiil dari Tuhan pada saat musim haji. Hal ini menandakan bahwa ikhtiar untuk mencari dan mendapatkan kecukupan hajat hidup merupakan satu keniscayaan dan menjadi pijakan etos kerja dalam pandangan Islam sebagaimana Q.S al-Baqarah (2) 198.

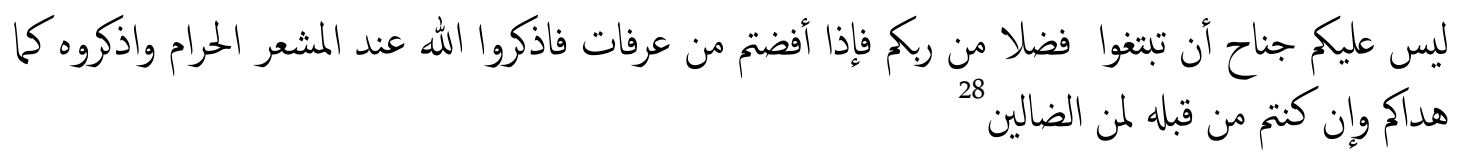

${ }^{26}$ Artinya: "Apabila telah ditunaikan shalat, maka bertebarlah kamu dimuka bumi, dan carilah karunia Allah dan ingatlah Allah banyak-banyak supaya kamu beruntung”. [Q.S al-Jumu'ah(62):10]

27 Artinya: Dan dia mendapatimu sebagai seorang yang kekurangan, lalu dia memberikan kecukupan. 
Menurut penulis, pengentasan kemiskinan dalam al-Quran dan Hadis terdapat bermacam faktor yang bisa ditemukan diantaranya:

\section{Faktor Individu}

Penulis mengidentifikasi upaya pengentasan kemiskinan di lihat dari faktor individu berikut:

\section{a. Perintah untuk bekerja Keras}

Memperhatikan akar kata miskin yang sebagian mengartikan diam atau tidak bergerak, memberikan kesan bahwa faktor utama penyebab kemiskinan adalah sikap berdiam diri, enggan, atau tidak dapat bergerak dan berusaha. Keengganan berusaha merupakan penganiayaan terhadap diri sendiri. Tuhan melalui Firman-Nya menegaskan kepada umat manusia untuk tidak bersikap malas, sebaliknya Tuhan senantiasa memerintahkan hamba-Nya untuk senantiasa bekerja dan berusaha untuk memperoleh rezeki dan anugerah dariNya yang ditegaskan dalam al-Quran dengan bunyi:

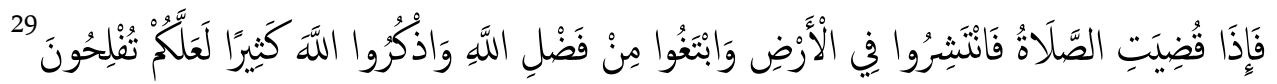

Bahkan al-Quran tidak memberi peluang bagi seseorang untuk menganggur sepanjang saat yang dialami dalam kehidupan dunia ini. Firman Tuhan:

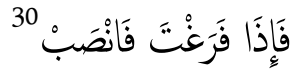

Menurut M. Quraish Shihab, kata faraghta terambil dari kata faragha, yang berarti "kosong setelah sebelumnya penub". Kata ini tidak digunakan kecuali untuk menggambarkan kekosongan yang didahului oleh kepenuhan, termasuk keluangan yang

${ }^{28}$ Artinya: Tidak ada dosa bagimu untuk mencari karunia (rizki hasil perniagaan) dari Tubanmu. Maka apabila kamu telah bertolak dari 'Arafah, berdzikirlah kepada Allab di Masy'arilharam. Dan berdzikirlah (dengan menyebut) Allah sebagaimana yang ditunjukan-Nya kepadamu dan sesunggubnya kamu sebelum ini benar-benar termasuk orang-orang yang sesat.

${ }^{29}$ Artinya: Apabila telah ditunaikan sembahyang, maka bertebaranlah kamu di muka bumi, dan carilah karunia Allah dan ingatlah Allah sebanyak-banyaknya supaya kamu beruntung. (QS. Al-Jumuah (62):10).

${ }^{30}$ Maka apabila engkeau telah selesai (dari suatu urusan) tetaplah bekerja keras untuk (urusan yang lain) (QS. Al-Insyirah; 94: 7). 
didahului oleh kesibukan. Seseorang yang telah memenuhi waktunya dengan pekerjaan, kemudian ia menyelesaikan pekerjaannya, maka waktu antara selesainya pekerjaan pertama dan dimulainya pekerjaan selanjutnya dinamai faragha. Ayat di atas berpesan, "Kalau engkau dalam keluangan sedang sebelumnya engkau telah memenuhi waktumu dengan kerja, maka fanshab". Kata fanshab antara lain berarti berat, letih. Pada mulanya ia berarti "menegakkan sesuatu sampai nyata dan mantap".

Anjuran bekerja keras sebagaimana diuraikan di atas merupakan satu cara mengatasi kemiskinan yang disebabkan oleh karena malas dan lemah kemauan serta sikap mental yang negatif lainnya. Sikap mental kerja keras ini perlu disuntikkan kepada mereka yang lemah kemauannya agar timbul semangat untuk bekerja mengubah nasibnya. Di dalam satu hadis dijelaskan bahwasanya setiap orang harus memanfaatkan waktu sebaiknya untuk bekerja keras dalam meraih kehidupan dunia,

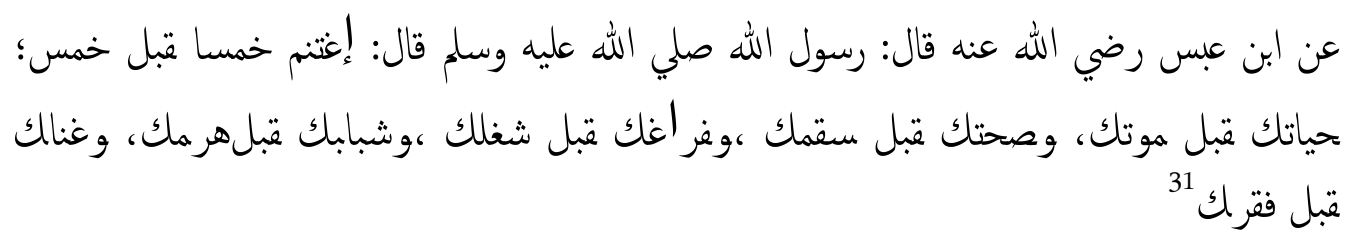

Betapa besar pahala yang diberikan oleh Tuhan kepada seorang yang bekerja keras untuk mencukupi kebutuhan dirinya dan keluarganya. Hal ini senada dengan hadis Rasullah menurut riwayat Ibn Majah berikut:

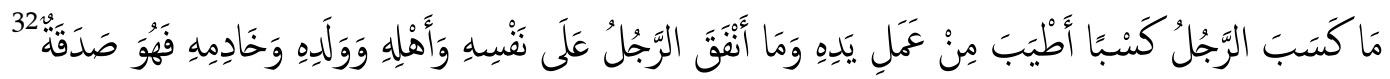

\section{b. Hidup hemat dan tidak berlebih-lebihan}

31 Artinya: Dari Ibn Abas r.a. berkata Rasulullah saw, bersabda: "memanfaatkan lima keadaan sebelum datangnya lima; masa hidup sebelum datang matimu, masa sehatmu sebelum sakitmu, masa luangmu sebelum masa sibukmu, masa muda sebelum masa tuamu dan masa kayamu sebelum masa fakirmu".

32 "Tidak ada yang lebih baik dari usaha seorang laki-laki kecuali dari hasil tangannya (bekerja) sendiri. Dan apa saja yang dinafkabkan oleb seorang laki-laki kepada diri, istri, anak dan pembantunya adalah sedekah." (HR. Ibnu Majah). 
Islam tidak menyukai sikap berlebih-lebihan. Tuhan melarang kita untuk berlebih-lebihan dalam segala perkara bahkan Tuhan menyatakan bahwa orang yang suka berlebih-lebihan termasuk saudaranya syaitan dengan firmanNya pada Surat alIsra' ayat 26-27 berikut:

Dan berikanlah kepada keluarga-keluarga yang dekat akan haknya, kepada orang miskin dan orang yang dalam perjalanan dan janganlah kamu menghambur-bamburkan (hartamu) secara boros. Sesunggubnya pemboros-pemboros itu adalah saudara-saudara syaitan dan syaitan itu adalah sangat ingkar kepada Tuhannya. (Q.S. Al-Isra': 26-27)

Di ayat yang lain Tuhan berfirman:

Dan dialah yang menjadikan kebun-kebun yang berjunjung dan yang tidak berjunjung, pobon korma, tanam-tanaman yang bermacam-macam buabnya, zaitun dan delima yang serupa (bentuk dan warnanya) dan tidak sama (rasanya). makanlah dari buabnya (yang bermacam-macam itu) bila dia berbuab, dan tunaikanlah haknya di hari memetik hasilnya (dengan disedekabkan kepada fakir miskin); dan janganlah kamu berlebih-lebihan. Sesunggubnya Allah tidak menyukai orang yang berlebih-lebihan. (Q.S. Al-An'am: 141)

\section{Faktor Lingkungan Sosial Kemasyarakatan}

Selain faktor individu, al-Quran dan hadis juga melihat adanya peran lingkungan sosial kemasyarakatan dalam mengentaskan kemiskinan. Beberapa faktor yang mempengaruhinya diantaranya:

\section{a. Zakat Produktif}

Al-Zakat dari segi bahasa berarti pertumbuhan, pertambahan, dan penyucian. Dari segi terminologi al-Zakat berarti harta yang dikeluarkan oleh manusia dari hak Tuhan untuk fukara. Dinamakan demikian karena pada zakat itu terdapat harapan untuk memperoleh berkah, menyucikan jiwa dan menghasilkan kebaikan yang berlipat ganda, jadi bisa dikatakan bahwa zakat merupakan harta yang wajib dikeluarkan dan mengandung sejumlah manfaat, baik bagi yang mengeluarkan zakat maupun yang mendapatkan zakat.

Informasi yang diberikan oleh Muhammad Fu'ad Abd al-Baqi bahwa di dalam al-Quran kata zakat di ulang sebanyak 32 kali yang hampir seluruhnya di sebut setelah perintah mengerjakan sholat. Ini menunjukkan bahwa kedudukan perintah zakat sejajar dengan perintah shalat dan keduanya saling melengkapi. Shalat lebih menunjukkan pada hubungan vertikal dengan Tuhan, sedangkan zakat merupakan 
ibadah yang memuat hubungan horizontal dengan manusia secara lebih menonjol. Dengan demikian terwujudlah hubungan yang seimbang antara berhubungan dengan Allah dan berhubungan dengan sesama manusia.

Perkara yang berada dalam genggaman tangan seseorang atau sekelompok orang, pada hakikatnya adalah milik Tuhan. Manusia diwajibkan menyerahkan kadar tertentu dari kekayaannya untuk kepentingan para saudara mereka. Hasil produksi dari berbagai bentuk pada hakikatnya merupakan pemanfaatan materi yang telah diciptakan dan dimiliki Tuhan. Jelas sudah bahwa keberhasilan orang kaya adalah atas keterlibatan banyak pihak, termasuk para fakir miskin "Kalian mendapat kemenangan dan kecukupan berkat orang-orang lemah di antara kalian.” Demikian Rasulullah bersabda, sebagaimana diriwayatkan oleh Abu Daud melalui Abu Ad-Darda'. Di dalam al-Quran ditegaskan:

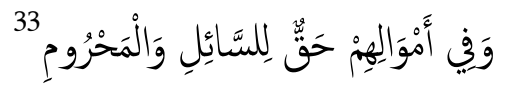

Jadi, di dalam kekayaan para orang kaya terdapat hak yang mesti dikeluarkan bagi orang yang memerlukan dan bagi orang miskin. Kewajiban menunaikan zakat yang demikian tegas dan mutlak di dalam ajaran Islam terkandung hikmah dan manfaat yang demikian besar dan mulia, baik yang berkaitan dengan muzakki, mustahik, harta benda yang dikeluarkan zakatnya, maupun bagi masyarakat secara keseluruhan. Setidaknya terdapat dua hikmah zakat dalam kaitannya dengan solusi zakat dalam upaya pengentasan kemiskinan diantaranya:

Pertama, prinsip pokok zakat pada dasarnya merupakan perwujudan iman kepada Tuhan, mensyukuri nikmat-Nya, menumbuhkan akhlak mulia dengan memiliki rasa kepedulian yang tinggi, menghilangkan sifat kikir dan rakus,

33 Dan pada barta benda mereka ada bak untuk orang miskin yang meminta, dan orang miskin yang tidak meminta, (QS. Az-Zariyat, 51:19) 
menumbuhkan ketenangan hidup, sekaligus mengembangkan dan mensucikan harta yang dimiliki (QS. At-Taubah, 9: 103, QS. Ar-Rum, 30:39, QS. Ibrahim, 14: 7).

Kedua, karena zakat merupakan hak bagi mustahik, maka berfungsi untuk menolong, membantu dan membina mereka, terutama golongan fakir miskin, ke arah kehidupan yang lebih baik dan lebih sejahtera, sehingga mereka dapat memenuhi kebutuhan hidupnya dengan layak, dapat beribadah kepada Tuhan, terhindar dari bahaya kekufuran, sekaligus menghilangkan sifat iri, dengki dan hasad yang mungkin timbul dari kalangan mereka ketika melihat golongan kaya yang berkecukupan hidupnya. Zakat, sesungguhnya bukan sekedar memenuhi kebutuhan yang bersifat konsumtif yang sifatnya sesaat, akan tetapi memberikan kecukupan dan kesejahteraan pada mereka, dengan cara menghilangkan atau memperkecil penyebab kehidupan mereka menjadi miskin dan menderita.

Pendayagunaan zakat secara produktif ini nampak lebih merupakan langkah mengatasi kemiskinan yang amat strategis. An-Nawawi dalam al-Majmu' sebagaimana di kutip Sofiah di dalam Kajian Tematik al-Quran, mengemukakan bahwa prinsip zakat produktif dapat digambarkan ketika seorang fakir miskin yang tenaganya mampu untuk bekerja, hendaknya diberi peralatan untuk bekerja sesuai dengan keahliannya atau diberi modal untuk berdagang agar mereka dapat melakukan perbaikan taraf hidupnya. Dengan demikian jelas, efektivitas zakat produktif akan lebih diberdayakan dengan solusi pemberian modal, dengan istilah lain memberikan pancing untuk mengail bukan hanya memberikan ikannya saja.

\section{b. Shadaqah atau Sedekah Produktif}

Shadaqah berarti harta yang yang dikeluarkan dengan maksud untuk mendekatkan diri kepada Tuhan untuk menyucikan diri. Tuhan menyebut sedekah sebagai "pinjaman yang baik" (qardhul hasan). Orang bersedekah hakikatnya meminjamkan harta kepada Tuhan dan dia pasti akan mengembalikan pinjaman dengan pengembalian yang berlipat ganda. Para mufasir menerjemahkan "pinjaman yang baik" dengan makna "menafkahkan harta di jalan Allah", yakni menyumbangkan harta (sedekah) untuk meringankan beban orang lain, seperti kaum 
dhuafa, fakir dan miskin. Penjelasan ini terdapat di dalam Q.S al-Baqarah:[2] 245 sebagaimana berikut:

Siapakah yang mau memberi pinjaman kepada Allah, pinjaman yang baik, maka Allah akan melipatgandakan pembayaran kepadanya dengan kelipatan yang banyak, dan Allah menyempitkan dan melapangkan (rezeki) dan kepada-Nyalab kamu dikembalikan". (QS. AlBaqarah: 245)

Sedekah yang paling baik adalah sedekah produktif, yaitu sedekah yang bisa membantu orang menjadi mandiri dan tak pernah habis. Sedekah produktif sering disebut juga dengan sedekah yang sifatnya memberikan modal bagi kaum fakir maupun miskin, bukan hanya memberikan uang saja sehingga diharapkan dengan pemberian modal, seseorang yang terpuruk ekonominya, bisa menata ekonominya menjadi lebih baik.

Imam muslim meriwayatkan dari Ibnu Umar ra, bahwa satu hari Umar Bin Khattab mendatangi Rasul dan berkata "Aku mendapatkan bagian tanah di Khaibar yang luar biasa produktif. Aku bahkan belum pernah mendapatkan harta yang lebih berharga dari Tanah itu. Apa yang sebaiknya kulakukan terhadap tanah itu. Rasulullah menjawab " Tahan modalnya, dan sedekahkan hasilnya." Lalu Umar menyedekahkan tanahnya itu untuk kaum dhuafa. Ia tidak boleh dimiliki perorangan, di jual atau dihibahkan, dan tidak diwariskan. Penggarap tanah dipersilahkan mengambil sebagian hasil panen secukupnya dan sebagian besar lainnya untuk fakir miskin di sekitar kebun.

\section{c. Infaq}

Al-Infaq adalah bentuk masdar dari kata kerja anfaqa yang antara lain berarti menghabiskan, melenyapkan. Kata ini di bentuk dari kata kerja lain yakni, nafaqa yang berarti berlalu, habis. Sebagai suatu istilah, Infaq berarti membelanjakan harta atau semacamnya jalan kebaikan. Kata infaq, dalam berbagai bentuknya terutama kata kerja bentuk lampau, sedang dan perintah banyak digunakan di dalam al-Quran 
untuk menggugah kesadaran orang yang beriman agar menginfaqkan sebagian dari harta yang mereka miliki. Kata kerja anfaqa adakalanya diikuti oleh objek secara langsung, adakalanya diikuti oleh objek dengan perantara partikel min (dari) ada kalanya tidak diikuti oleh objek. Pada pemakaian yang bervariasi ini terdapat penekanan makna yang beragam, namun terkait satu sama lain.

Kata yang biasanya dijadikan sebagai objek langsung dari kata anfaqa adalah mal yang artinya harta benda. (missal Q.S al-Baqarah [2]: 262). Adapun ungkapan yang digunakan sebagai objek tidak langsung antara lain 1). Mima razaqnqkum yang berarti sebagaian dari rizki yang kami berikan kepadamu (Q.S al-Baqarah [2]: 245) 2). Min Thayyibat yang berarti dari suatu yang baik (Q.S al-Baqarah [2]: 267) 3). Min Khair yang berarti dari yang baik (Q.S al-Baqarah [2]: 272) 4). Mima Tubibbun yang berarti dari apa yang kamu cintai (Q.S ali Imran [3]: 92) sedangkan kata anfaqa yang tidak disertai dengan objek adalah (Q.S al-Furqan [25]: 67).

Berdasarkan pemaparan dia atas dapat dikatakan bahwa pada umumnya yang di minta untuk diinfakan adalah karunia Allah berupa harta dan benda. Sasaran infak dinyatakan dalam ungkapan yang mengandung makna luas yaitu fi sabilillah (Q.S alBaqarah [2]: 261) sedangkan sasaran infak yang bersifat khusus seperti kedua orang tua, kerabat serta kaum fakir dan miskin (Q.S al-Baqarah [2]: 215) sehingga diharapkan dengan banyak orang yang mengeluarkan infak baik kaum fakir miskin, makin banyak orang yang dapat ditolong dalam mengentaskan kemiskinan.

\section{G. Kesimpulan}

Berdasarkan uraian di atas dapat diajukan kesimpulan, bahwa di dalam alQuran setidaknya ada sepuluh kosakata yang menyangkut kemiskinan 1). alMaskanat, 2). al-Faqr 3). al-a'ilat, 4). al-ba'sa 5). al-Imalaq 6). al-Sail 7). al-Mahrum 8). alQani'9). al-Mu'tar 10). al-Dhaif dan al-Mustadh'af. Satu term yang terkandung dari kosa kata di atas adalah term kemiskinan materi.

Berbicara kemiskinan, ayat di dalam al-Quran banyak menekankan kepada manusia yang lebih baik taraf hidupnya untuk membantu mereka yang miskin dan menanggulangi kesulitan hidup yang dihadapi dan agar mereka tidak terjerumus 
kedalam perbuatan yang dapat merendahkan martabatnya. Tuntutan ini sejalan dengan dengan tujuan syariat Islam yang dimaksudkan untuk kesejahteraan manusia lahir dan batin.

Dalam melawan kemiskinan, al-Quran dan hadis memberikan tuntunan yang dapat digunakan sebagai pegangan. Tuntunan yang berasal dari individu meliputi kerja keras, dan hidup sederhana sedangkan tuntunan yang berasal dari sosial kemasyarakatan yakni meliputi pengelolaan zakat produktif dan mengeluarkan sedekah produktif serta infak. 


\section{DAFTAR PUSTAKA}

Al-Ashfahany. al-Raghib. 1992. Mufradz al-Faz̧ al-Quran. Bairut: al- Dar al-Saamiyyah.

Al-Baqiy, M Fuad 'Abd.1986. al-Mu'jam al-mufahras li al-Fadz al-Quran al-Karim. Bairut: Dar al-Fikr.

Al-Ghazali, Muhammad. 1987. Al-Islam wa Auda' al-Iqtishadiyah. Kairo: Dar al-Riyan.

Hasan, Nasihin. 1986. Kepedulian Sosial dalam Beragama, Majalah Pesantre. No.2/Vol.III.

Hijazy, M Mahmud. 1968. al-Tafsir al-wadhi, juz III, (Kairo: Mathaba’ at-Istiqlal al-Qubra.

Qardawy, Yusuf. 1986. Musykilat al-Faqr wa Kaifa 'Alajaha' al-Islam. Kairo: Maktabah Wahbat. 1993. Al-Muntaqa. al-Manshurah:Dar al-Wafa'. 1997. Sistem Masyarakat Islam dalam al-Qura'an dan Sunah. Solo: Citra Islam Press.

Shihab. M Quraish. 1997.Wawasan al-Quran; Tafsir Maudu'I atas Berbagai Persoalan Ummat Bandung: al-Mizan.

Suparlan. Parsudi (ed), 1995. Kemiskinan di Perkotaan. Jakarta: Yayasan Obor Indonesia. Tim Penyusun, Kamus Besar Bahasa Indonesia (Jakarta: Balai Pustaka, 1990) Wargadinata. Wildana. 2001. Islam dan Pengentasan Kemiskinan,( Malang: UIN Maliki Press.

Zakariya. Ibn, 1997. Mu’jam Mawayis al-Lughat, jilid V (Mesir: Musthasfa al Baby alHalaby. 